\title{
Exploring the Continuous Usage Intention of Online Learning Platforms from the Perspective of Social Capital
}

\author{
Chun-Hsiung Huang
}

Citation: Huang, C.-H. Exploring the Continuous Usage Intention of Online Learning Platforms from the Perspective of Social Capital. Information 2021, 12, 141. https:// doi.org/10.3390/info12040141

Academic Editor: Willy Susilo

Received: 4 March 2021

Accepted: 22 March 2021

Published: 25 March 2021

Publisher's Note: MDPI stays neutral with regard to jurisdictional claims in published maps and institutional affiliations.

Copyright: (C) 2021 by the author. Licensee MDPI, Basel, Switzerland. This article is an open access article distributed under the terms and conditions of the Creative Commons Attribution (CC BY) license (https:// creativecommons.org/licenses/by/ $4.0 /)$.
Department of Digital Content Design, Ling Tung University, Taichung 408213, Taiwan; huangch@teamail.ltu.edu.tw

\begin{abstract}
This research explores the factors that influence students' continuous usage intention regarding online learning platforms from the perspectives of social capital, perceived usefulness, and perceived ease of use. The questionnaire survey method was used in the research to analyze the relationship between the research variables and verify the hypothesis based on data from 248 collected valid questionnaire responses. The following results were obtained: (1) "Social interaction ties" positively affect students' continuous usage intention. (2) "Shared language" negatively affects students' continuous usage intention. (3) "Shared vision" positively affects students' continuous usage intention. (4) "Perceived usefulness" positively affects students' continuous usage intention. (5) "Perceived ease of use" positively affects students' continuous usage intention. According to the results, students believe in useful teaching that promotes knowledge and skills. The ease of use of learning tools is key to whether they can learn successfully. Paying attention to the interaction and communication between students, so that students have a shared goal and participate in teamwork, is something that teachers must pay attention to in the course of operation. The professional vocabulary of the teaching content and the way of announcing information should avoid using difficult terminology, which is also a point to which teachers need to pay attention.
\end{abstract}

Keywords: online learning; social capital; perceived usefulness; perceived ease of use; continuous usage intention

\section{Introduction}

In the era of knowledge economy, educational organizations have the responsibility of cultivating outstanding talents and strengthening national competitiveness. Countries around the world have invested a lot of manpower, material resources, and funds to apply information and communication technologies, which have brought new opportunities to change the type and content of learning. Learners can conduct learning activities according to their individual needs at a time and place that suits themselves. The popularity of wired networks and the technological advancement of wireless ones have allowed online learning to be integrated into a more diverse and innovative learning platform in a more immediate, flexible, and autonomous mode.

In the original online learning system, Internet technology was used to deliver learning content to learners. Students learned by reading and completing assignments, while instructors used the Internet to evaluate the quality of students' assignments. Most of that online learning focused on the setting of the online course system, which allows learners and instructors to conduct synchronous or asynchronous learning across space and time. The current online learning system was constructed by enhancing the concept of cooperative learning. Learners can learn and discuss collaboratively with online peers. Through students learning from each other in the social community, the effectiveness of online learning can be enhanced.

In college education, there is a significant relationship between online learners' computer self-efficacy, perceived usefulness, confirmation, and satisfaction [1]. Continuous 
usage intention of online learning is determined by satisfaction [2]. Learners' computer anxiety, teachers' attitudes toward e-learning, flexibility of digital learning courses, digital learning course quality, perceived usefulness, perceived ease of use, and diversity in assessments are the key factors affecting learner satisfaction [3]. The social capital theory states that through close social interaction, individuals can increase the depth, breadth, and efficiency of mutual knowledge exchange [4]. Cocquyt et al. [5] explored social inclusion and social capital based on blended learning, they found that peer support was positively correlated with social connectedness and social capital.

Nevertheless, little attention has been paid to the role of social capital in building students' continuance intention in the context of online learning platforms. In the year of 2020, due to the coronavirus disease 2019 (COVID-19) pandemic, most students around the world needed to use online learning systems to conduct distance education at home. Therefore, the current paper aims to test the role of social capital, perceived usefulness, and perceived ease of use in driving students to continue using online learning platforms. The findings have implications for strengthening the implementation of online learning further on.

\section{Literature Review}

\subsection{Online Learning}

Online learning is one type of e-learning. Govindasamy [6] believed that the Internet, satellite broadcasting, interactive screens, and compact disc teaching materials used for course learning all belong to the category of digital learning. Clark and Mayer [7] believed that online learning is the use of an organization's internal network or external Internet to deliver teaching content to learners. This teaching method can be synchronous or asynchronous. The synchronous method means that the learners and the instructors are online at the same time. The asynchronous method means that the learners can study the course content at different points in time. Nowadays, with the progress of the times and the improvement of wireless network technology, online learning methods can break through the limitations of time and space. General speaking, online learning is the use of wired or wireless network transmission technology to conduct synchronous or asynchronous learning. Rosenberg [8] described the " $\mathrm{e}$ " in e-learning as representing three functional facets: experience, extension, and expansion. Among them, "experience" means that e-learning can change the user's experience in the learning process; "extension" means that learners can continue learning through e-learning at any time; and "expansion" means using e-learning which provides teaching services anywhere outside the classroom.

Online learning provides flexibility in learning schedules. Students can obtain learning content anytime and anywhere. Online learning also provides a variety of different courses to choose from, so that students can control their learning time and will have opportunities for more interaction and communication $[9,10]$. Online learning allows participants of all ages, genders, and educational levels to participate in learning activities. It also covers learners from different cultural and regional backgrounds, enabling them to participate and overcome any curriculum restrictions in any subject [11,12]. Online learning allows learners to have a higher degree of autonomy. However, because students are not in a fixed classroom, under instructors' supervision, learners must be able to have self-discipline and learn spontaneously. They also need to be responsible for their own learning [13]. Learners in online courses with a higher degree of virtualization will not able to be face-to-face and see body language from other class members, which makes learning lonelier and more stressed [14]. Online learning cannot provide a rich social environment and direct interaction opportunities like traditional face-to-face learning methods. It is usually difficult to achieve a good social experience [15]. Therefore, using the establishment of an online learning community to promote virtual interactions [16] and to explore the relationship between social capital and online learning platforms can provide a reference for building systems on online learning platforms. 


\subsection{Social Capital Theory}

Social capital is the sum of real or potential resources. These resources come from long-term and stable networks of interpersonal relationships. Social capital is shared by all members, and all network members can use these resources [17]. It can also be said to be the sum of all the scales of the relationship network that an individual can effectively mobilize and the quality of capital owned by all members of the network [18]. Coleman [19] pointed out that there are many specific benefits in the relationship structures between people. In order to achieve their own benefits, people exchange information through trust and interactions among themselves and form eternal social relations.

From the point of view of the network, Putnam [20] mentioned that social capital is a social network accompanied by trust, norms, and reciprocity. Through the highly reciprocal and connected groups among network members, social capital increases personal identification and cognition. It also ensures personal values such as intimacy, reciprocity, mutual trust, and other frequent interactive relationships. In addition to being a part of the entire social structure, these social relations are also a social resource, and this social resource is social capital [21]. Adler and Kwon [22] also believed that social capital exists in social networks. Individuals establish special social relationships through interactions with others. Actors can obtain resources or information through interactive relationships as well.

Nahapiet and Ghoshal [18] proposed three dimensions of social capital in their research on social capital, intellectual capital, and organizational knowledge as the concept of the composition of social capital theory. The structural dimension focuses on observing the connection patterns between actors. The structural aspect includes three components: network ties, network configuration, and appropriable organization. The cognitive dimension focuses on the representations, interpretations, and systems of meaning which the actors share with others. The cognitive aspect includes two components: codes and language, and narratives. The relational dimension focuses on the interpersonal relationships between actors and others because of long-term interaction. The relationship aspect includes four components: trust, identification, obligations and expectation, and norms.

\subsection{Perceived Usefulness and Perceived Ease of Use}

The technology acceptance model (TAM) was proposed by Davis [23], based on the theory of reasoned action (TRA). He believed that the external factors that affect users' acceptance of new technologies are through two key intermediary factors-perceived usefulness and perceived ease of use-which affect users' behavioral intention. Fishbein and Ajzen [24] proposed the theory of reasoned action (TRA) to explain the influence process of people's behavior, which is an important theoretical basis of the technology acceptance model (TAM). The related studies have shown that the higher the user's intention to use a new system, the greater the number and frequency of instances of actual use of the system $[25,26]$.

The perceived usefulness is defined as a person's perception that the product or new technology can effectively improve the efficiency of completing a specific task using a product or new technology. The perceived usefulness expresses the user's performance expectations for work or study. The more useful the user perceives a certain technology to be, the more positively they will view systems that use the technology. The perceived ease of use is defined as the degree to which an individual believes a product or new technology is easy to use and easy to learn. If a user believes that the product or new technology is easier to use, they will be more willing to continue using the technology. When users think that a certain technology is easier to use, they will have a more positive attitude towards systems that use the technology.

\subsection{Continuous Usage Intention}

Oliver [27] put forward the expectation confirmation theory to explain that the user's satisfaction will affect their willingness to reuse a product in the future. In other words, 
when a product or service is used by the user, if it meets the user's expectations, the user will have the intention to continue using it. After analyzing the expectation confirmation theory, Bhattacherjee [28] believed that a user's decision to continue to use an information system is similar to a consumer's repurchase intention. Therefore, he proposed the IS Continuance Model. The continuous use mode of the information system can explain the user's experience after using the information system, so that it affects the intention to continue to use the system in the future. The IS continuance model states that IS continuous usage intention is affected by satisfaction with the system and the perceived usefulness of the system. Satisfaction is affected by the perceived usefulness and confirmation. The confirmation also affects the perceived usefulness. Intention refers to the tendency of an individual to act and can predict a person's behavior. In the study of the IS Continuance Model, continuous usage intention is an important factor for the success of the system. The user's decision to continue using the system (or not) is determined by the strength of their continuous use intention $[29,30]$.

\section{Methodology}

\subsection{Research Structure}

This study explores the continuous usage intention of online learning platforms. The main motivation for this is that many universities around the world needed to adopt online learning methods for classes and learning in the year of 2020. Although the COVID-19 pandemic is well controlled in Taiwan, schools of higher education still need to conduct multiple online teaching and online learning exercises under the regulations published by the Ministry of Education in Taiwan. Faculty members use online video conferencing as one of the main teaching tools in Ling Tung University, Taichung, Taiwan. The online learning platform of this research refers to the use of Zoom, WebEx, Microsoft Teams, and other software in response to the COVID-19 pandemic. School teachers can use online video conferences in order to teach classes and conduct real-time group broadcasts and discussions with students. Hypotheses H1-H8 in this study were derived as shown in Figure 1.

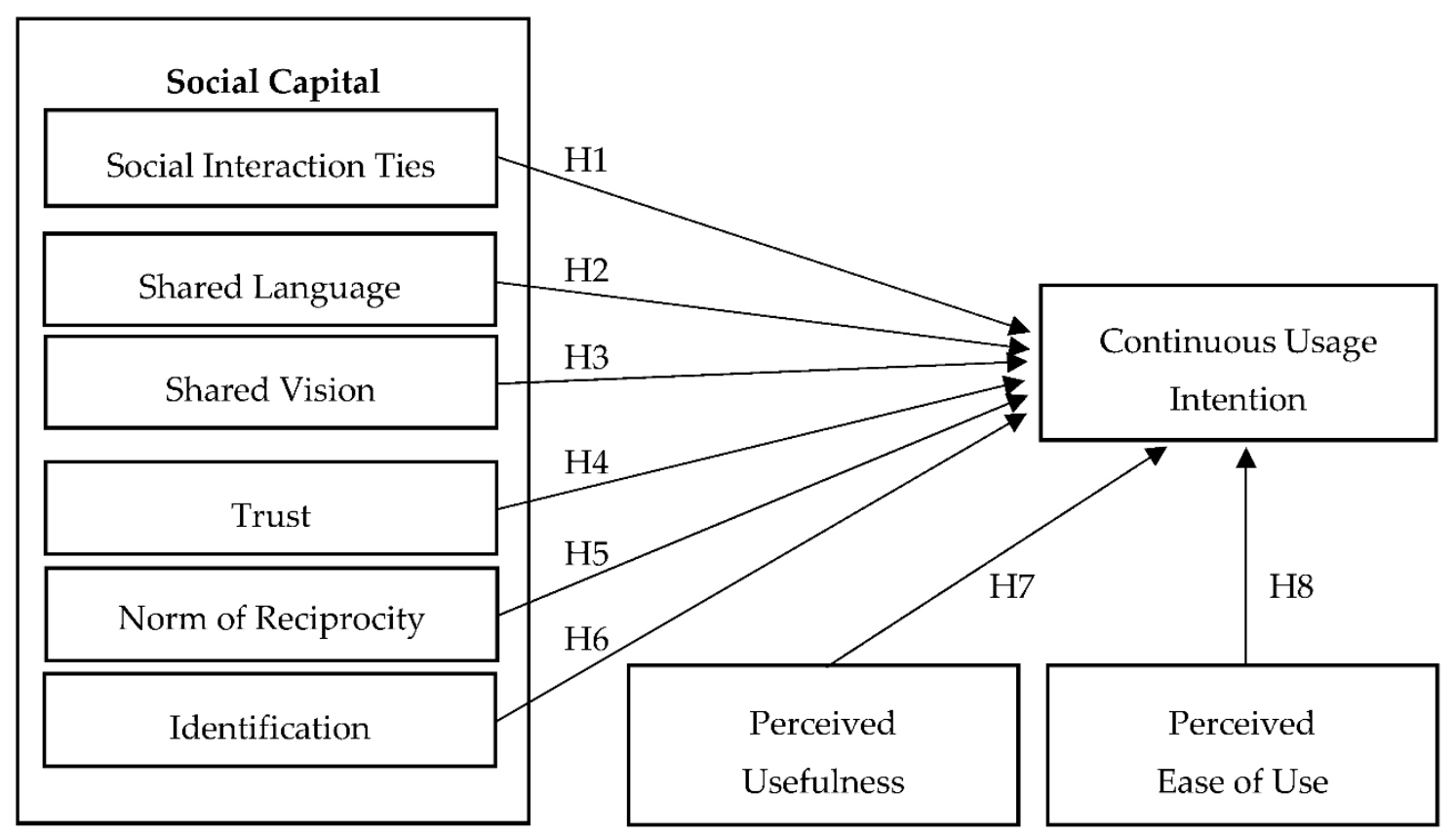

Figure 1. Research model. 


\subsection{Research Hypotheses}

While studying how online communities affect the quality of knowledge sharing, this research was also based on the three-dimensional structure of social capital [31] and its proposed components, such as social interaction ties, shared language, shared vision, trust, norm of reciprocity, and identification. The social interaction ties link refers to the strength of the relationships between the community members in the virtual community, the frequency of communication, and the time spent. Shared language refers to the words that are shaped by the interaction of daily life. It allows community members to understand the community's collective goals and appropriate communication methods. Shared vision means that community members have shared goals and aspirations. Trust is the personal expectation that members will follow a set of generally accepted values, norms, and principles in the community. The norm of reciprocity is mutual and equal exchange of knowledge between two parties in a social network environment. Identification refers to the individual's sense of belonging and positive feelings towards the virtual community. This research refers to and adopts the social capital dimension proposed by Chiu et al. [31].

Social capital is an important driving force for the success of online brand communities [32], and it is also widely used to explain human behavior in social interaction research [33]. The structural aspect of social capital can be the relationships between individuals and groups. Online learning platforms allow users to interact with others in order to form a network of social relationships. The structural dimension of social capital is measured by social interaction ties, which is the most frequently used factor in the social capital literature [34]. Huang et al. [35] pointed out that social interaction ties are one of the factors that affect pass-along email intentions. On the other hand, the cognitive dimension of social capital is measured by perceived similarity, which is one of the important factors in social capital literature [36]. The cognitive aspect of social capital includes two concepts: shared language and shared vision. Shared language refers to that established between communities to help cooperative learning and increase communication efficiency; shared vision refers to community members having shared goals and similar values. Will these two concepts affect the continuous usage intention of online learning platforms? This is also a factor that this study was planned to explore. The relational aspect of social capital is the development of a specific relationship of trust, norm of reciprocity, and identification between network members through long-term mutual communication. Some studies on information system services also proposed that there is a relationship between trust and use intention $[37,38]$. Therefore, this research proposes the following hypotheses:

Hypothesis 1: Social interaction ties affect students' continuous usage intention regarding online learning platforms.

Hypothesis 2: Shared language affects students' continuous usage intention regarding online learning platforms.

Hypothesis 3: Shared vision affects students' continuous usage intention regarding online learning platforms.

Hypothesis 4: Trust affects students' continuous usage intention regarding online learning platforms.

Hypothesis 5: The norm of reciprocity affects students' continuous usage intention regarding online learning platforms.

Hypothesis 6: Identification affects students' continuous usage intention regarding online learning platforms.

The perceived ease of use and perceived usefulness are two dimensions in the acceptance model of technology. Some scholars have pointed out that the perceived ease of use will directly affect the user's attitude and behavioral intention to use [39,40]. The perceived 
usefulness will also positively affect the user's intention to use [41,42]. In addition, the perceived usefulness is one of the factors that affects continuous usage intention in the IS Continuance Model [28]. Weng et al. [43] also found that perceived usefulness and perceptual ease of use are important factors influencing the willingness to continue using a system when studying the intention to continue using taxi reservation services. Therefore, this research proposes the following:

Hypothesis 7: The perceived usefulness affects students' continuous usage intention regarding online learning platforms.

Hypothesis 8: The perceived ease of use affects students' continuous usage intention regarding online learning platforms.

\subsection{Definition and Measurement of Research Dimensions}

For all dimensions of this study, relevant studies in the literature were referred to in order to define and operate variables. As for the question of measuring the facts, the "social capital" question item was modified from Chiu et al. [31], in which social capital was divided into the structural dimension, cognitive dimension, and relationship dimension. The social interaction ties belong to the structural dimension. Shared language and shared vision belong to the cognitive dimension. Trust, the norm of reciprocity, and identification belong to the relationship dimension. The question items for the "perceived usefulness" and "perceived ease of use" scale were modified from Hwang et al. [44]. The question items for the "continuous usage intention" scale were modified from Liao and Lu [45]. The definitions of the research dimensions and operation types are shown in Table 1, and the questionnaire items and reference sources for the scale are shown in Tables 2-4.

Table 1. The operational definitions and reference sources.

\begin{tabular}{|c|c|c|}
\hline Dimension & Operational Definition & Source \\
\hline Social Interaction Ties & $\begin{array}{l}\text { The strength of the relationship between members } \\
\text { of the online learning platform, the frequency of } \\
\text { communication, and the time spent. }\end{array}$ & \multirow{6}{*}{ Chiu et al. [31] } \\
\hline Shared Language & $\begin{array}{l}\text { The long-term interactions of online learning } \\
\text { platform members shape the degree to which they } \\
\text { can easily understand the words of others. }\end{array}$ & \\
\hline Shared Vision & $\begin{array}{l}\text { Members of the online learning platform have } \\
\text { shared goals and ambitions. }\end{array}$ & \\
\hline Trust & $\begin{array}{l}\text { Members of the online learning platform believe } \\
\text { that other members will follow a set of generally } \\
\text { accepted values, norms, and principles. }\end{array}$ & \\
\hline Norm of Reciprocity & $\begin{array}{l}\text { Members of the online learning platform believe } \\
\text { that it is fair to share relevant learning information } \\
\text { with each other. }\end{array}$ & \\
\hline Identification & $\begin{array}{l}\text { Members of the online learning platform have a } \\
\text { sense of belonging and a positive sense in the class. }\end{array}$ & \\
\hline Perceived Usefulness & $\begin{array}{l}\text { Students think that online learning platforms are } \\
\text { very helpful for acquiring knowledge. }\end{array}$ & \multirow{2}{*}{ Hwang et al. [44] } \\
\hline Perceived Ease of Use & $\begin{array}{l}\text { Students think that the online learning platform is } \\
\text { easy to use. }\end{array}$ & \\
\hline Continuous Usage Intention & $\begin{array}{l}\text { Students will continue to use online learning } \\
\text { platforms in the future. }\end{array}$ & Liao and Lu [45] \\
\hline
\end{tabular}


Table 2. Questionnaire items referenced from Chiu et al. [31].

\begin{tabular}{|c|c|}
\hline Dimension & Question \\
\hline \multirow{4}{*}{ Social Interaction Ties } & $\begin{array}{l}\text { I maintain a very close relationship with some of my students who } \\
\text { are on the online learning platform. }\end{array}$ \\
\hline & $\begin{array}{l}\text { I spent a lot of time interacting with other students who were on the } \\
\text { online learning platform. }\end{array}$ \\
\hline & $\begin{array}{l}\text { I know the personal information of other students who are on the } \\
\text { online learning platform. }\end{array}$ \\
\hline & $\begin{array}{l}\text { I often communicate with other students who are on the online } \\
\text { learning platform. }\end{array}$ \\
\hline \multirow{3}{*}{ Shared Language } & $\begin{array}{l}\text { I think that the students on the online learning platform use a } \\
\text { common language. }\end{array}$ \\
\hline & $\begin{array}{l}\text { I think that the students who are attending classes on the online } \\
\text { learning platform use professional terms that they all understand } \\
\text { when discussing relevant learning information. }\end{array}$ \\
\hline & $\begin{array}{l}\text { I think that when students in class together on the online learning } \\
\text { platform discuss relevant learning information, they use a way of } \\
\text { knowing each other to post information. }\end{array}$ \\
\hline \multirow{3}{*}{ Shared Vision } & $\begin{array}{l}\text { I think that the students in classes together on the online learning } \\
\text { platform have a common vision to help each other and solve each } \\
\text { other's problems. }\end{array}$ \\
\hline & $\begin{array}{l}\text { I think that the students in classes together on the online learning } \\
\text { platform have the same goal of learning from each other. }\end{array}$ \\
\hline & $\begin{array}{l}\text { I think that the students in classes together on the online learning } \\
\text { platform think that helping others is a pleasure. }\end{array}$ \\
\hline \multirow{4}{*}{ Trust } & $\begin{array}{l}\text { I think that the students who take classes together on the online } \\
\text { learning platform do not take advantage of others. }\end{array}$ \\
\hline & $\begin{array}{l}\text { I think that the students who take classes together on the online } \\
\text { learning platform are trustworthy. }\end{array}$ \\
\hline & $\begin{array}{l}\text { I think that the students who take classes together on the online } \\
\text { learning platform respect the conversations or statements of others. }\end{array}$ \\
\hline & $\begin{array}{l}\text { I think that the students who take classes together on the online } \\
\text { learning platform interact with others in a sincere manner. }\end{array}$ \\
\hline \multirow{3}{*}{ Norm of Reciprocity } & $\begin{array}{l}\text { I know that other students who are on the online learning platform } \\
\text { will help me, so it is fair to help each other. }\end{array}$ \\
\hline & $\begin{array}{l}\text { I believe that when I need help, other students who are on the online } \\
\text { learning platform will also help me. }\end{array}$ \\
\hline & $\begin{array}{l}\text { Even if I can't help other students now, I believe that the students } \\
\text { who are in class with the online learning platform will help me. }\end{array}$ \\
\hline \multirow{4}{*}{ Identification } & $\begin{array}{l}\text { I have a sense of belonging to the class on the online } \\
\text { learning platform. }\end{array}$ \\
\hline & $\begin{array}{l}\text { I have a sense of cohesion or intimacy with the class on the online } \\
\text { learning platform. }\end{array}$ \\
\hline & $\begin{array}{l}\text { I have strong positive emotions for the class on the online } \\
\text { learning platform. }\end{array}$ \\
\hline & $\begin{array}{l}\text { I am proud of being a member of the class on the online } \\
\text { learning platform. }\end{array}$ \\
\hline
\end{tabular}


Table 3. Questionnaire items referenced from Hwang et al. [44].

\begin{tabular}{|c|c|}
\hline Dimension & Question \\
\hline \multirow{6}{*}{ Perceived Usefulness } & I think that online learning platforms enrich learning activities. \\
\hline & $\begin{array}{l}\text { I think that online learning platforms are very helpful for me to } \\
\text { obtain knowledge. }\end{array}$ \\
\hline & $\begin{array}{l}\text { I think that the learning mechanism provided by the online learning } \\
\text { platform makes the learning process smoother. }\end{array}$ \\
\hline & $\begin{array}{l}\text { I think that online learning platforms help me get useful information } \\
\text { when I need it. }\end{array}$ \\
\hline & I think that online learning platforms help me learn better. \\
\hline & $\begin{array}{l}\text { I think that online learning platforms are more useful than traditional } \\
\text { classroom teaching methods. }\end{array}$ \\
\hline \multirow{6}{*}{ Perceived Ease of Use } & $\begin{array}{l}\text { I think that the online learning platform operating system is not } \\
\text { difficult for me. }\end{array}$ \\
\hline & $\begin{array}{l}\text { It only took me a short time to fully understand how to use the online } \\
\text { learning platform. }\end{array}$ \\
\hline & $\begin{array}{l}\text { I think that the learning activities on online learning platforms are easy } \\
\text { to understand and follow. }\end{array}$ \\
\hline & I learned to use the online learning platform very quickly. \\
\hline & $\begin{array}{l}\text { I think that the learning methods used in online learning platforms are } \\
\text { not difficult for me. }\end{array}$ \\
\hline & I think that the system of the online learning platform is easy to use. \\
\hline
\end{tabular}

Table 4. Questionnaire items referenced from Liao and Lu [45].

\begin{tabular}{ll}
\hline \multicolumn{1}{c}{ Dimension } & \multicolumn{1}{c}{ Question } \\
\hline & $\begin{array}{l}\text { If there is a need for learning in the future, I will use the online } \\
\text { learning platform for learning. }\end{array}$ \\
\cline { 2 - 2 } Continuous Usage Intention & $\begin{array}{l}\text { In addition to necessary use in the future, I will also actively } \\
\text { increase the frequency of use of online learning platforms } \\
\text { for learning. }\end{array}$ \\
\cline { 2 - 2 } & $\begin{array}{l}\text { I would suggest to others to use the online learning platform } \\
\text { for learning. }\end{array}$ \\
\hline
\end{tabular}

\section{Research Results}

Likert's 5-point scale was adopted in this research scale, which was distributed among and answered by freshmen to juniors in the Digital Content Design Department of Ling Tung University in Taiwan. These students who completed the questionnaire all had at least one month of online video class experience. A total of 248 valid questionnaires were collected. First of all, SPSS version 22.0 was used as the computer statistical analysis software, and the statistical analysis carried out included reliability analysis and the KaiserMeyer-Olkin (KMO) validity test. Next, correlation analysis was used to understand the relationships between the dimensions. Finally, regression analysis was applied to understand the degree of mutual influence of the dimensions.

\subsection{Reliability Analysis}

Reliability is a measure of the dependence of a tool. According to Cronbach [46], if Cronbach's alpha is greater than 0.7 , the reliability is quite high; if it is between 0.7 and 0.35 , it is acceptable; and if it is less than 0.35 , the reliability is low. A total of 248 valid questionnaires were collected for this study. There are nine dimensions of Cronbach's alpha values: social interaction ties, shared language, shared vision, trust, norm of reciprocity, 
identification, perceived usefulness, perceived ease of use, and continuous usage intention. They were all higher than 0.7 (between 0.722 and 0.939) (please refer to Table 5). This shows that the questionnaire in this study is within the acceptable reliability range and has good internal consistency.

Table 5. Reliability analysis table.

\begin{tabular}{ccc}
\hline Dimension & Number of Questions & Cronbach's Alpha Value \\
\hline Social Interaction Ties & 4 & 0.722 \\
Shared Language & 3 & 0.766 \\
Shared Vision & 3 & 0.866 \\
Trust & 4 & 0.887 \\
Norm of Reciprocity & 3 & 0.918 \\
Identification & 4 & 0.933 \\
Perceived Usefulness & 6 & 0.933 \\
Perceived Ease of Use & 6 & 0.939 \\
Continuous Usage Intention & 3 & 0.914 \\
\hline
\end{tabular}

\subsection{Validity Analysis}

The questionnaire design in this research was completed with the assistance of three relevant experts with experience in designing questionnaires, and the semantics of the question items were modified to have certain expert validity. In addition, we used the KMO spherical test to check whether they were independent of each other. The commonly used metrics of KMO are as follows [47]: above 0.9 means very suitable; above 0.8 means suitable; above 0.7 means generally suitable; below 0.6 means not suitable; below 0.5 means extremely unsuitable. Therefore, the KMO statistic takes a value between 0 and 1 . When the sum of squares of the simple correlation coefficients among all variables is much larger than the sum of squares of the partial correlation coefficients, the KMO value is close to 1. The overall results of this test are summarized in Table 6.

Table 6. The KMO spherical test results.

\begin{tabular}{ccc}
\hline Dimension & KMO Value & Result \\
\hline Social Interaction Ties & $0.740^{* *}$ & Generally Suitable \\
Shared Language & $0.701^{* *}$ & Generally Suitable \\
Shared Vision & $0.727^{* *}$ & Generally Suitable \\
Trust & $0.833^{* *}$ & Suitable \\
Norm of Reciprocity & $0.737^{* *}$ & Generally Suitable \\
Identification & $0.846^{* *}$ & Suitable \\
Perceived Usefulness & $0.914^{* *}$ & Very Suitable \\
Perceived Ease of Use & $0.890^{* *}$ & Suitable \\
Continuous Usage Intention & $0.754^{* *}$ & Generally Suitable \\
\hline
\end{tabular}

** significant at $p<0.01$.

The KMO value of social interaction ties was 0.740 , which passed the verification standard. The explainable variation was greater than $55.823 \%$, so one component was extracted. The shared language KMO value was 0.701 , which passed the verification standard, and the explainable variation was greater than $68.808 \%$, extracting one component. The KMO value of shared vision was 0.727 , which passed the verification standard. The explainable variation was greater than $78.940 \%$, so one component was extracted. The trust $\mathrm{KMO}$ value was 0.833 , passing the verification standard. The explainable variation was greater than $74.943 \%$, so one component was extracted. The norm of reciprocity KMO value was 0.737 , which passed the verification standard. The explainable variation was greater than $85.953 \%$, so one component was extracted. Identification had a KMO value of 0.846 , passing the verification standard. The explainable variation was greater than $83.375 \%$, so one component was extracted. The perceived usefulness KMO value was 0.914 , which passed the verification standard. The explainable variation was greater than 
$75.379 \%$, so one component was extracted. The perceived ease of use KMO value was 0.890 , which passed the verification standard. The explainable variation was greater than $76.677 \%$, so one component was extracted. The continuous usage intention KMO value was 0.754 , which passed the verification standard. The explainable variation was greater than $85.365 \%$, so one component was extracted. Therefore, all dimensions of this study passed the standards with certain validity.

\subsection{Correlation Analysis}

Before the regression analysis, we performed Pearson correlation analysis. Correlation analysis is often used to explore the linear correlation between two continuous variables $(\mathrm{X}, \mathrm{Y})$. If the absolute value of the correlation coefficient between the two variables is large, it means that they are mutually covariant to a greater extent. First of all, we conducted correlation analysis to understand whether there is a relationship between the various dimensions, as preparation for regression analysis, and the results are presented in Table 7.

Table 7. Pearson correlation analysis.

\begin{tabular}{|c|c|c|c|c|c|c|c|c|c|}
\hline & $\begin{array}{c}\text { Social } \\
\text { Interaction Ties }\end{array}$ & $\begin{array}{l}\text { Shared } \\
\text { Language }\end{array}$ & $\begin{array}{l}\text { Shared } \\
\text { Vision }\end{array}$ & Trust & $\begin{array}{l}\text { Norm of } \\
\text { Reciprocity }\end{array}$ & Identification & $\begin{array}{l}\text { Perceived } \\
\text { Usefulness }\end{array}$ & $\begin{array}{c}\text { Perceived } \\
\text { Ease of Use }\end{array}$ & $\begin{array}{c}\text { Continuous } \\
\text { Usage } \\
\text { Intention }\end{array}$ \\
\hline $\begin{array}{c}\text { Social } \\
\text { Interaction Ties }\end{array}$ & 1 & & & & & & & & \\
\hline Shared Language & $0.559 * *$ & 1 & & & & & & & \\
\hline Shared Vision & $0.588^{* *}$ & $0.719 * *$ & 1 & & & & & & \\
\hline Trust & $0.580 * *$ & $0.597 * *$ & $0.737^{* *}$ & 1 & & & & & \\
\hline $\begin{array}{l}\text { Norm of } \\
\text { Reciprocity }\end{array}$ & $0.526^{* *}$ & $0.559 *$ & $0.658^{* *}$ & $0.674^{* *}$ & 1 & & & & \\
\hline Identification & $0.645^{* *}$ & $0.533^{* *}$ & $0.647^{* *}$ & $0.656^{* *}$ & $0.702 * *$ & 1 & & & \\
\hline $\begin{array}{l}\text { Perceived } \\
\text { Usefulness }\end{array}$ & $0.582 * *$ & $0.505^{* *}$ & $0.668^{* *}$ & $0.637^{* *}$ & $0.652 * *$ & $0.754^{* *}$ & 1 & & \\
\hline $\begin{array}{c}\text { Perceived Ease of } \\
\text { Use }\end{array}$ & $0.558^{* *}$ & $0.528^{* *}$ & $0.586^{* *}$ & $0.612 * *$ & $0.570 * *$ & $0.567^{* *}$ & $0.720 * *$ & 1 & \\
\hline $\begin{array}{c}\text { Continuous } \\
\text { Usage Intention }\end{array}$ & $0.571 * *$ & $0.442 * *$ & $0.616^{* *}$ & $0.587^{* *}$ & $0.548^{* *}$ & $0.623 * *$ & $0.799 * *$ & $0.719 * *$ & 1 \\
\hline
\end{tabular}

** significant at $p<0.01$.

\subsection{Regression Analysis}

Table 7 shows that there were correlations between the dimensions. Next, we conducted further regression analysis to clarify the relationship between those dimensions. The eight dimensions of social interaction ties, shared language, shared vision, trust, norm of reciprocity, identification, perceived usefulness, and perceived ease of use were used as independent variables. The students' continuous usage intention regarding online learning platforms was used as the dependent variable for regression analysis. The results are shown in Table 8 and Figure 2. The hypotheses are established as shown in Table 9.

Table 8. The results of regression analysis.

\begin{tabular}{cc}
\hline Independent Variable/Dependent Variable & Continuous Usage Intention \\
\hline Social Interaction Ties & $0.116^{*}$ \\
Shared Language & $-0.115^{*}$ \\
Shared Vision & $0.143^{*}$ \\
Trust & 0.025 \\
Norm of Reciprocity & -0.045 \\
Identification & -0.016 \\
Perceived Usefulness & $0.525^{* *}$ \\
Perceived Ease of Use & $0.280^{* *}$ \\
Significance & $0.000^{* *}$ \\
Degree of Freedom & 9 \\
F Value & 60.944 \\
$\mathrm{R}^{2}$ & 0.697 \\
\hline
\end{tabular}




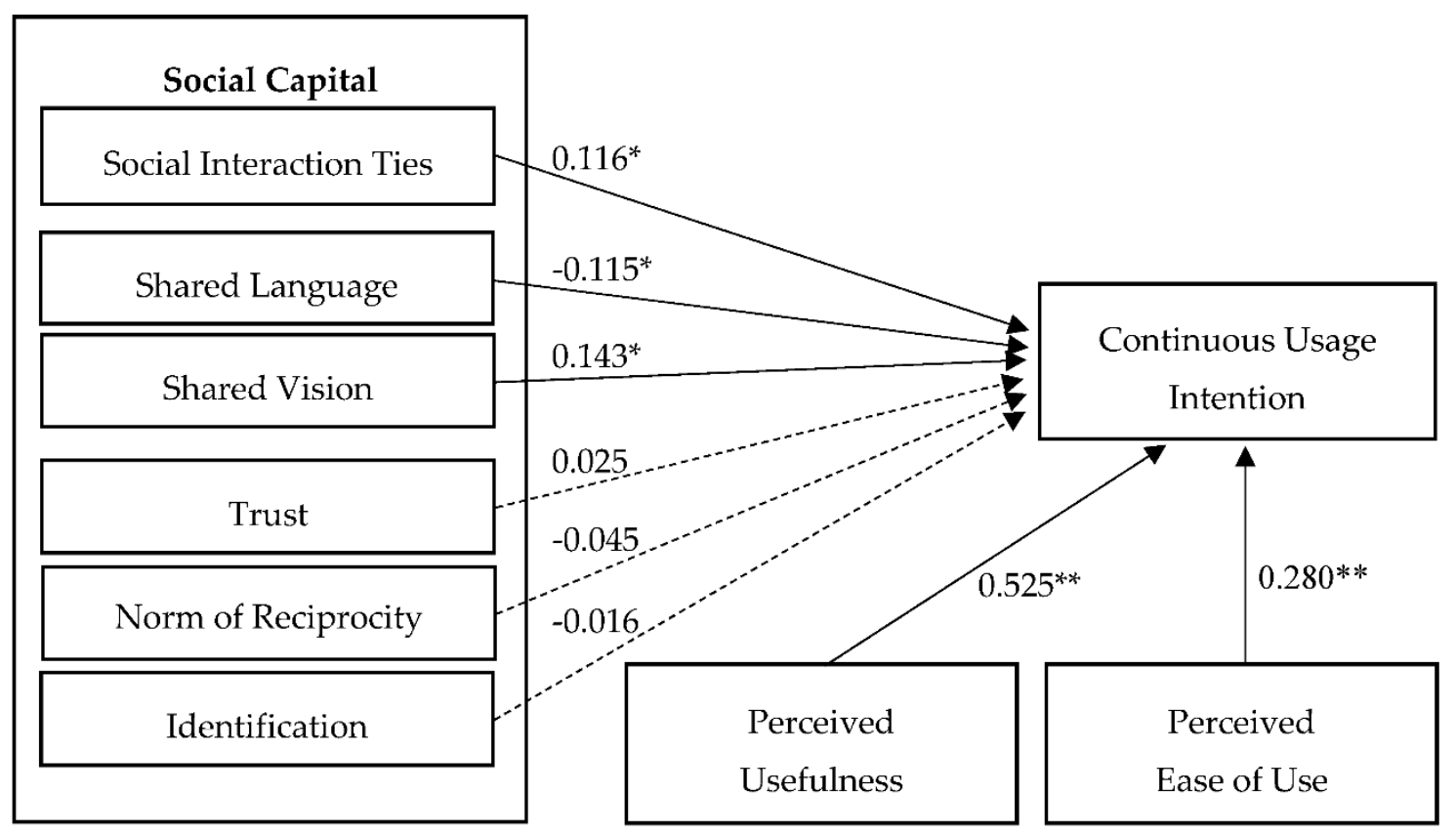

Figure 2. The results of regression analysis ( ${ }^{*}$ significant at $p<0.05 ;{ }^{* *}$ significant at $\left.p<0.01\right)$.

Table 9. The established hypotheses.

\begin{tabular}{lc}
\hline \multicolumn{1}{c}{ Hypothesis } & Condition \\
\hline $\begin{array}{l}\text { Hypothesis 1: Social interaction ties affect students' continuous usage intention } \\
\text { regarding online learning platforms. }\end{array}$ & Valid \\
\hline $\begin{array}{l}\text { Hypothesis 2: Shared language affects students' continuous usage intention regarding } \\
\text { online learning platforms. }\end{array}$ & Valid \\
\hline $\begin{array}{l}\text { Hypothesis 3: Shared vision affects students' continuous usage intention regarding } \\
\text { online learning platforms. }\end{array}$ & Valid \\
\hline $\begin{array}{l}\text { Hypothesis 4: Trust affects students' continuous usage intention regarding online } \\
\text { learning platforms. }\end{array}$ & Invalid \\
\hline $\begin{array}{l}\text { Hypothesis 5: The norm of reciprocity affects students' continuous usage intention } \\
\text { regarding online learning platforms. }\end{array}$ & Invalid \\
\hline $\begin{array}{l}\text { Hypothesis 6: Identification affects students' continuous usage intention regarding } \\
\text { online learning platforms. }\end{array}$ & Invalid \\
\hline $\begin{array}{l}\text { Hypothesis 7: The perceived usefulness affects students' continuous usage intention } \\
\text { regarding online learning platforms. }\end{array}$ & Valid \\
\hline $\begin{array}{l}\text { Hypothesis 8: The perceived ease of use affects students' continuous usage intention } \\
\text { regarding online learning platforms. }\end{array}$ & Valid \\
\hline
\end{tabular}

\section{Conclusions}

\subsection{Research Conclusions}

In addition to the good reliability and validity of this study, when discussing the impact relationship, we also found that the most important factor affecting students' willingness to continue using the online video learning platform is the perceived usefulness. In other words, what students care most about is whether they can really gain knowledge and skills via this way of teaching. As the perceived ease of use is valid, it can also be considered that the use of online video conferencing tools must be simple and easy. Especially for students who have not used online video conferencing before, the online conferencing software for class teaching must be simple and intuitive to use. It is best not to have too many settings and complicated functions for them to apply. When students were asked about the use of online video conferencing, the students also agreed that Zoom and 
WebEx are far simpler and more convenient to use than Microsoft Teams. Regarding shared vision, this study supports the view that students who may have a shared goal in class together will encourage, help, and support each other. There is a saying that one person walks fast, and a group of people walks far; such is the case with learning. In study, we also support partners who have a shared goal and support each other. This has an impact on the promotion of continued use as well. The social interaction ties are the discovery of frequent exchanges and interactions among students, which is also one of the factors that affects continuous usage intention. However, shared language negatively affected the students' willingness to continue using the system, which is strange. This may be due to the fact that professional terminology is too difficult for students, which makes students unwilling to use it. In addition, the relationship dimension of social capital has not yet been deemed valid. This may be due to the fact that the online learning platform has not been used for a sufficient amount of time, and the students have not yet established the interpersonal relationships developed by long-term interaction with other students.

This research suggests that regarding teaching strategies and methods, no matter what kind of online learning platform tools are used, students believe that useful teaching that promotes knowledge and skills and easy-to-use learning tools are the key to successful learning. Teachers also can increase the chances of success of their teaching. In the meantime, the teacher can pay attention to the interaction and communication among students, so that students have a shared goal and participate in teamwork. This is something that teachers must pay attention to when operating the courses. The professional vocabulary of the teaching content and the way of announcing information should avoid difficult terminology, which is also a point to which teachers need to pay attention.

\subsection{Limitations and Further Research}

First of all, because this research was conducted in the Department of Digital Content Design of Ling Tung University, the use of convenience sampling may have given results different from the implementation status of other schools in Taiwan. Therefore, there are limitations, and the results must be inferred for different locations with restrictions. It is recommended to use a larger sample size and random sampling from different schools to collect samples. Structural equation modeling (SEM) can be used to analyze the data. In addition to reducing deviations, this can also expand the universality of result inferences.

Secondly, the social capital measurement adopted in this study was based on Chiu et al.'s six-subdimensional model [31]. Social capital is widely used to explain the network and interaction of social media. There is no consensus on the measurement model of social capital. As further suggestions, it can also be compared with Lin and Lu's threedimensional model [21] and Williams's two-dimension model [48].

Finally, in order to have a better understanding of the influence of social capital on the intention to continue using online learning platforms, a more ideal research design is a longitudinal analysis over different periods. However, the data collected in this study limit this analysis. Thus, future studies could examine usage behaviors on online learning platforms using a longitudinal analysis.

Funding: This research received no external funding.

Institutional Review Board Statement: Not applicable.

Informed Consent Statement: Not applicable.

Data Availability Statement: Data is contained within the article. For further questions, please contact the authors.

Conflicts of Interest: The author declares no conflict of interest. 


\section{References}

1. Wu, J.P.; Tsai, R.J.; Chen, C.C.; Wu, Y.C. An integrative model to predict the continuance use of electronic learning systems: Hints for teaching. Int. J. E-Learn. 2006, 5, 287-302.

2. Roca, J.C.; Chiu, C.M.; Martínez, F.J. Understanding e-learning continuance intention: An extension of the technology acceptance model. Int. J. Hum.-Comput. Stud. 2006, 64, 683-696. [CrossRef]

3. Sun, P.C.; Tsai, R.J.; Finger, G.; Chen, Y.Y.; Yeh, D. What drives a successful e-Learning? An empirical investigation of the critical factors influencing learner satisfaction. Comput. Educ. 2008, 50, 1183-1202. [CrossRef]

4. Lane, P.J.; Lubatkin, M.H. Relative absorptive capacity and interorganizational learning. Strateg. Manag. J. 1998, 19, 461-477. [CrossRef]

5. Cocquyt, C.; Zhu, C.; Diep, A.N.; Greef, M.D.; Vanwing, T. Examining the role of learning support in blended learning for adults' social inclusion and social capital. Comput. Educ. 2019, 142, 103610. [CrossRef]

6. Govindasamy, T. Successful implementation of e-learning: Pedagogical considerations. Internet High. Educ. 2001, 4, 287-299. [CrossRef]

7. Clark, R.C.; Mayer, R.E. E-Learning and the Science of Instruction: Proven Guidelines for Consumers and Designers of Multimedia Learning; John Wiley \& Sons: New York, NY, USA, 2016; pp. 8-10.

8. Rosenberg, M.J. E-Learning: Strategies for Delivering Knowledge in the Digital Age; McGraw-Hill: New York, NY, USA, 2001; pp. 28-29.

9. Aldholay, A.; Isaac, O.; Abdullah, Z.; Abdulsalam, R.; Al-Shibami, A.H. An extension of Delone and McLean IS success model with self-efficacy: Online learning usage in Yemen. Int. J. Inf. Learn. Technol. 2018, 35, 285-304. [CrossRef]

10. Aldholay, A.; Isaac, O.; Abdullah, Z.; Ramayah, T. The role of transformational leadership as a mediating variable in DeLone and McLean information system success model: The context of online learning usage in Yemen. Telemat. Inform. 2018, 35, 1421-1437. [CrossRef]

11. Liu, X.; Liu, S.; Lee, S.; Magjuka, R.J. Cultural differences in online learning: International student perceptions. Educ. Technol. Soc. 2010, 13, 177-188.

12. $\mathrm{Xu}, \mathrm{J} . ;$ Rees, T. Distance learning course design expectations in China and the United Kingdom. Am. J. Distance Educ. 2016, 30, 250-263. [CrossRef]

13. Mupingo, D.M.; Nora, R.T.; Yaw, D.C. The learning styles, expectations, and needs of online students. Coll. Teach. 2006, 54, 185-189. [CrossRef]

14. Rovai, A.P. Building classroom community at a distance: A case study. Educ. Technol. Res. Dev. 2001, 49, 33-48. [CrossRef]

15. Symeonides, R.; Childs, C. The personal experience of online learning: An interpretative phenomenological analysis. Comput. Hum. Behav. 2015, 51, 539-545. [CrossRef]

16. Liu, X.; Magjuka, R.J.; Bonk, C.J.; Lee, S.H. Does sense of community matter? An examination of participants' perceptions of building learning communities in online courses. Q. Rev. Distance Educ. 2007, 8, 9-24.

17. Bourdieu, P. The forms of capital. Handbook of Theory and Research for the Sociology of Education; Richardson, J.G., Ed.; Greenwood Press: Westport, CT, USA, 1986; pp. 241-258.

18. Nahapiet, J.; Ghoshal, S. Social capital, intellectual capital, and the organizational advantage. Acad. Manag. Rev. 1998, 23, 242-266. [CrossRef]

19. Coleman, J.S. Social capital in the creation of human capital. Am. J. Sociol. 1988, 94, S95-S120. [CrossRef]

20. Putnam, R.D. Tuning in, tuning out: The strange disappearance of social capital in America. Am. Political Sci. Assoc. 1995, 28, 664-683. [CrossRef]

21. Lin, K.Y.; Lu, H.P. Intention to continue using Facebook fan pages from the perspective of social capital theory. Cyberpsychology Behav. Soc. Netw. 2011, 14, 565-570. [CrossRef] [PubMed]

22. Adler, P.S.; Kwon, S.W. Social capital: Prospects for a new concept. Acad. Manag. Rev. 2002, 27, 17-40. [CrossRef]

23. Davis, F.D. Perceived usefulness, perceived ease of use, and user acceptance of information technology. MIS Q. 1989, 13, 319-340. [CrossRef]

24. Fishbein, M.; Ajzen, I. Belief, Attitude, Intention, and Behavior: An Introduction to Theory and Research; Addison-Wesley: Reading, MA, USA, 1975; pp. 13-18.

25. Lee, M.C. Explaining and predicting users' continuance intention toward e-learning: An extension of the expectation-confirmation model. Comput. Educ. 2010, 54, 506-516. [CrossRef]

26. Cheon, J.; Lee, S.; Crooks, S.M.; Song, J. An investigation of mobile learning readiness in higher education based on the theory of planned behavior. Comput. Educ. 2012, 59, 1054-1064. [CrossRef]

27. Oliver, R.L. A cognitive model of the antecedents and consequences of satisfaction decisions. J. Mark. Res. 1980, 17, 460-469. [CrossRef]

28. Bhattacherjee, A. Understanding information systems continuance: An expectation-confirmation model. MIS Q. 2001, 25, 351-370. [CrossRef]

29. Hong, S.J.; Tam, K.Y. Understanding the adoption of multipurpose information appliances: The case of mobile data services. Inf. Syst. Res. 2006, 17, 162-179. [CrossRef]

30. Thong, J.Y.L.; Hong, S.J.; Tam, K.Y. The effects of post-adoption beliefs on the expectation-confirmation model for information technology continuance. Int. J. Hum.-Comput. Stud. 2006, 64, 799-810. [CrossRef] 
31. Chiu, C.M.; Hsu, M.H.; Wang, E.T.G. Understanding knowledge sharing in virtual communities: An integration of social capital and social cognitive theories. Decis. Support Syst. 2006, 42, 1872-1888. [CrossRef]

32. Meek, S.; Ryan, M.; Lambert, C.; Ogilvie, M. A multidimensional scale for measuring online brand community social capital (OBCSC). J. Bus. Res. 2019, 100, 234-244. [CrossRef]

33. Kim, J.; Kang, S.; Lee, K.H. How social capital impacts the purchase intention of sustainable fashion products. J. Bus. Res. 2020, 117, 596-603. [CrossRef]

34. Yang, S.; Liu, Y.; Wei, J. Social capital on mobile SNS addiction: A perspective from online and offline channel integrations. Internet Res. 2016, 26, 982-1000. [CrossRef]

35. Huang, C.C.; Lin, T.C.; Lin, K.J. Factors affecting pass-along email intentions (PAEIs): Integrating the social capital and social cognition theories. Electron. Commer. Res. Appl. 2009, 8, 160-169. [CrossRef]

36. Fu, S.; Yan, Q.; Feng, G.C. Who will attract you? Similarity effect among users on online purchase intention of movie tickets in the social shopping context. Int. J. Inf. Manag. 2018, 40, 88-102. [CrossRef]

37. Li, D.; Browne, G.J.; Chau, P.Y.K. An empirical investigation of web site use using a commitment-based model. Decis. Sci. 2006, 37, 427-444. [CrossRef]

38. Chen, S.C.; Yen, D.C.; Hwang, M.I. Factors influencing the continuance intention to the usage of web 2.0: An empirical study. Comput. Hum. Behav. 2012, 28, 933-941. [CrossRef]

39. Nysveen, H.; Pedersen, P.E.; Thorbjørnsen, H. Explaining intention to use mobile chat services: Moderating effects of gender. J. Consum. Mark. 2005, 22, 247-256. [CrossRef]

40. Castañeda, J.A.; Muñoz-Leiva, F.; Luque, T. Web acceptance model (WAM): Moderating effects of user experience. Inf. Manag. 2007, 44, 384-396. [CrossRef]

41. Moon, J.W.; Kim, Y.G. Extending TAM for a world wide web context. Inf. Manag. 2001, 38, 217-230. [CrossRef]

42. Heijden, H. Factors influencing the usage of websites: The case of a generic portal in the Netherlands. Inf. Manag. 2003, 40, 541-549. [CrossRef]

43. Weng, G.S.; Zailani, S.; Iranmanesh, M.; Hyun, S.S. Mobile taxi booking application service's continuance usage intention by users. Transp. Res. Part D Transp. Environ. 2017, 57, 207-216. [CrossRef]

44. Hwang, G.J.; Yang, L.H.; Wang, S.Y. A concept map-embedded educational computer game for improving students' learning performance in natural science courses. Comput. Educ. 2013, 69, 121-130. [CrossRef]

45. Liao, H.L.; Lu, H.P. The role of experience and innovation characteristics in the adoption and continued use of e-learning websites. Comput. Educ. 2008, 51, 1405-1416. [CrossRef]

46. Cronbach, L.J. Coefficient alpha and the internal structure of tests. Psychometrika 1951, 16, 297-334. [CrossRef]

47. Kaiser, H.F. An index of factorial simplicity. Psychometrika 1974, 39, 31-36. [CrossRef]

48. Williams, D. On and off the 'net: Scales for social capital in an online era. J. Comput.-Mediat. Commun. 2006, 11, 593-628. [CrossRef] 